\title{
Artificial insertion of peptides between signal peptide and mature protein: effect on secretion and processing of hybrid thermostable $\alpha$-amylases in Bacillus subtilis and Escherichia coli cells
}

\author{
Yoshiki Itoh, ${ }^{1}$ KoH-IChi Kanoh, ${ }^{1}$ Kouji NaKamura, ${ }^{1}$ Kenji TAKaSE $^{2}$ and Kunio Yamane ${ }^{1}$ * \\ ${ }^{1}$ Institute of Biological Sciences, University of Tsukuba, Tsukuba-shi, Ibaraki 305, Japan \\ ${ }^{2}$ Department of Molecular Biology, National Institute of Agrobiological Resources, Tsukuba-shi, Ibaraki 305, Japan
}

(Received 23 November 1989; revised 23 March 1990; accepted 20 April 1990)

\begin{abstract}
To study the effect of inserted peptides on the secretion and processing of exported proteins in Bacillus subtilis and Escherichia coli, pBR322-derived DNA fragments coding for small peptides were inserted between the DNA coding for the 31 amino acid $B$. subtilis $\alpha$-amylase signal peptide and that coding for the mature part of the extracellular thermostable $\alpha$-amylase of $B$. stearothermophilus. Most of the inserted peptides (21 to 65 amino acids) decreased the production of the enzyme in $B$. subtilis and $E$. coli, the effect of each peptide being similar in the two strains. In contrast, with one peptide (a 21 amino acid sequence encoded by the extra DNA in pTUBE638), the production of $\alpha$-amylase was enhanced more than 1.7-fold in $B$. subtilis in comparison with that of the parent strain. The molecular masses of the thermostable $\alpha$-amylases in the periplasm of the $E$. coli transformants varied for each peptide insert, whereas those in the culture supernatants of the $B$. subtilis transformants had molecular masses similar to that of the mature enzyme. Based on the $\mathrm{NH}_{2}$-terminal amino acid sequence of the hybrid protein from pTUBE638, it was shown that in $E$. coli, the $\mathrm{NH}_{2}$-terminally extended thermostable $\alpha$-amylase was translocated and remained in the periplasm after the 31 amino acid signal sequence was removed. In the case of $B$. subtilis, after the removal of a 34-amino acid signal sequence, the hybrid protein was secreted and processed to the mature form.
\end{abstract}

\section{Introduction}

Secreted proteins are usually synthesized as precursors with a short $\mathrm{NH}_{2}$-terminal extension called the signal peptide which promotes the initiation of secretion and which is removed by a specific enzyme (Blobel \& Dobberstein, 1975; Davis \& Tai, 1980). Some precursors also contain propeptides, which are usually located between the signal peptide and the mature enzyme, and which are removed after secretion. The presence of propeptides has been reported in Bacillus subtilis $\alpha$-amylase (Takase et al., 1988), B. subtilis alkaline and neutral proteases (Wong \& Doi, 1986; Yang et al., 1984; Ikemura et al., 1987), B. licheniformis penicillinase (Nielsen \& Lampen, 1982), Staphylococcus aureus nuclease A (Shortle, 1983), Saccharomyces cerevisiae $\alpha$-factor (Fuller et al., 1988), and mammalian proteases and polypeptide hormones (Neurath \& Walsh, 1976;

\footnotetext{
Abbreviations: DTT, dithiothreitol; $p$-APMSF, ( $p$-amidinophenyl)methanesulphonyl fluoride hydrochloride; $\operatorname{amy} E, \alpha$-amylase gene of Bacillus subtilis; amyT, thermostable $\alpha$-amylase gene of Bacillus stearothermophilus A631.
}

Steiner et al., 1980). The role, if any, of these propeptides in protein translocation is not certain; however, in the case of subtilisin the propeptide plays an important role in the modulation of enzyme activity (Ikemura et al., 1987; Ikemura \& Inouye, 1988). The amino acid sequences and lengths of the propeptides differ widely among proteins.

The precursor protein of $B$. subtilis $\alpha$-amylase is synthesized as a preproenzyme (Yamazaki et al., 1983). A comparison of the amino acid sequence deduced from the DNA nucleotide sequence of the $\alpha$-amylase gene $(a m y E)$ and the $\mathrm{NH}_{2}$-terminal amino acid sequence of the extracellular mature $\alpha$-amylase (Mäntsälä \& Zalkin, 1979 ) indicated that the precursor contains an $\mathrm{NH}_{2}$-terminal extension of 41 amino acid residues. However, recent experiments using deletion mutants (Sasamoto et al., 1989) and analysis of intermediates in the processing of extracellular $\alpha$-amylase suggested that the first 33 amino acid residues from the $\mathrm{NH}_{2}$-terminus constitute the signal peptide of this enzyme in $B$. subtilis (Takase et al., 1988).

In order to investigate the effect of artificially inserted peptides between the signal sequence and the mature 
protein on the secretion of exported proteins, and to analyse alteration of signal peptide cleavage sites in $B$. subtilis and $E$. coli cells, we constructed artificial amy $E^{\prime}-$ 'pBR322'- $a m y T$ fusion genes. In these fusion genes various small DNA fragments obtained from the $E$. coli plasmid pBR322 were inserted between the DNA encoding the first 31 amino acid residues of the amyE signal peptide and the DNA encoding the mature part of thermostable $\alpha$-amylase ('amyT) from $B$. stearothermophilus A631 (Sohma et al., 1987). The 31 amino acid sequence was used because the response to the modification of the amino acid sequence around the $a m y E$ signal peptide cleavage site in the two strains can be easily analysed. The thermostable $\alpha$-amylase was used as the marker enzyme because the amyT product does not contain a natural propeptide. Also, the structural gene for the mature thermostable $\alpha$-amylase is expressed well from the $a m y E$ promoter, and the $a m y E$ signal peptide is functional both in $E$. coli and in $B$. subtilis. The expression of $a m y E$ in $E$. coli was, however, only $3 \%$ of that obtained in B. subtilis (Sasamoto et al., 1989).

\section{Methods}

Bacterial strains, plasmids and culture conditions. Escherichia coli $\mathrm{HB} 101$ ( $\mathrm{F}^{-}$hsdS20 recAl3 ara-14 proA2 lacYl galK2 rpsL20 xyl-5 mtl-1 sup44 $\left.\lambda^{-}\right)$and Bacillus subtilis 207-25 ( $\mathrm{m}_{168}^{-}$hsrM recE4 amyE07 aroI906 lys-21 leuA8), an $\alpha$-amylase deficient strain (Yamazaki et al., 1983), were used as host cells.

The $B$. subtilis $-E$. coli shuttle plasmid pTUBE627 contains the $a m y E^{\prime}-{ }^{\prime} a m y T$ fused gene, in which the DNA sequence encoding the $B$. subtilis $\alpha$-amylase promoter and the 31 amino acids of its signal peptide $\left(a m y E^{\prime}\right)$ is fused to the DNA sequence encoding the extracellular mature thermostable $\alpha$-amylase ('amyT), using HindIII linker DNA. The 'amyT gene, which lacks its own promoter and signal peptide coding region, was derived from the chromosomal DNA of B. stearothermophilus A631 (Sohma et al., 1987). For the construction of pTUBE627, B. subtilis plasmid pUB110 containing the replication origin of pBR322 (DraI-PvuII $1.4 \mathrm{~kb}$ fragment) was used as the vector. E. coli and $B$. subtilis cells were grown with shaking at $37^{\circ} \mathrm{C}$ in L-broth [ $1 \%$ Bacto-tryptone (Difco), $0.5 \%$ yeast extract (Difco) and $0.5 \% \mathrm{NaCl}$ ] as described previously (Yamane et al., 1982).

Isolation and analysis of plasmid and chromosomal DNAs. Plasmid DNA was prepared by the rapid alkaline method of Birnboim \& Doly (1979). It was purified by $\mathrm{CsCl}$ equilibrium centrifugation in the presence of ethidium bromide, followed by agarose gel electrophoresis and subsequent recovery using hydroxyapatite (Tabak \& Flavell, 1978). DNA fragments were recovered from gels using DE81 paper (Dretzen et al., 1981). Restriction fragments to be sequenced were ligated into the BamHI site of the M13 mp19 phage (Yanisch-Perron et al., 1985), and the DNA sequences were determined by the dideoxy chaintermination method of Sanger et al. (1977). Restriction enzymes, T4 DNA ligase, Klenow fragment of DNA polymerase I and bacterial alkaline phosphatase were obtained from Takara Shuzo Co. or BRL, and HindIII linker DNA (5'GGAAGCTTCC $3^{\prime}$ ) from Pharmacia.

Transformation of E. coli and B. subtilis. E. coli HB101 was transformed by the method of Lederberg \& Cohen (1974), and B. subtilis 207-25 by the protoplast transformation method of Chang \& Cohen (1979).
Assay of thermostable $\alpha$-amylase activity. Amylase activity was measured at $60{ }^{\circ} \mathrm{C}$ by a slight modification of the method of Fuwa (1954), using $0.5 \%$ soluble starch as the substrate. Hydrolysis of $0.1 \mathrm{mg}$ starch in 1 min was defined as 1 unit (U) of enzyme activity.

Detection of thermostable $\alpha$-amylases by SDS-PAGE. $\alpha$-Amylases in the periplasmic fractions of $E$. coli cells and in the culture supernatants of $B$. subtilis cells were precipitated with $6.25 \%(\mathrm{w} / \mathrm{v}) \mathrm{TCA}$, dissolved in $0.1 \%$ SDS, dialysed against $25 \mathrm{~mm}$-Tris/ $\mathrm{HCl}$ buffer ( $\mathrm{pH} 7.5$ ) containing $192 \mathrm{~mm}$-glycine and $0.1 \% \mathrm{SDS}$, and boiled for $3 \mathrm{~min}$ in $1 \% \mathrm{SDS} / 1 \%$ mercaptoethanol. The samples were subjected to SDS-PAGE using an $8.5 \%(w / v)$ running gel (Laemmli, 1970). After electrophoresis, thermostable $\alpha$-amylases in the gels were renatured in situ by the method of Lacks \& Springhorn (1980), and then visualized by incubation of the gels in $1 \%$ soluble starch solution (pH 6.2 ) at $37^{\circ} \mathrm{C}$ for $2 \mathrm{~h}$ followed by dipping in $0.01 \mathrm{M}-\mathrm{KI} / \mathrm{I}_{2}$ solution. The molecular mass markers used were: bovine serum albumin $(68 \mathrm{kDa})$, ovalbumin $(43 \mathrm{kDa})$, carbonic anhydrase $(30 \mathrm{kDa})$ and cytochrome $c(12 \cdot 3 \mathrm{kDa})$.

Purification of $\mathrm{NH}_{2}$-terminally extended thermostable $\alpha$-amylases. $\mathrm{NH}_{2}$-terminally extended thermostable $\alpha$-amylases from the periplasm of $24 \mathrm{~h} \mathrm{E}$. coli cultures and from the culture supernatants of 12 and $36 \mathrm{~h}$ $B$. subtilis cultures were purified by the method described previously (Takase et al., 1988). To minimize proteolysis during the purification steps, crude $\alpha$-amylase preparations were treated with $0.2 \mathrm{~mm}$ p-APMSF and passed through columns $(1.2 \times 5 \mathrm{~cm})$ of Toyopearl HW55 (Toso Co.) in the presence of ammonium sulphate $(25 \%$ saturation) and $0.1 \mathrm{~mm}$-DTT. All steps were performed at $4{ }^{\circ} \mathrm{C}$. The preparations were then electrophoresed on SDS-polyacrylamide gels $(8.5 \%, \mathrm{w} / \mathrm{v})$ and the bands corresponding to the thermostable $\alpha$-amylases were blotted onto polybrene-coated glass filters (Whatman, $\mathrm{GF} / \mathrm{C}$ ) by the method of Vandekerckhove et al. (1985). The purified extended thermostable $\alpha$-amylase preparation obtained from the $24 \mathrm{~h}$ culture of $E$. coli HB101(pTUBE638) was designated pTUBE638$\alpha$-amylase (E24). The purified enzyme preparations from the 12 and $36 \mathrm{~h}$ culture supernatants of $B$. subtilis 207-25(pTUBE638) were designated pTUBE638- $\alpha$-amylase (B12) and pTUBE638- $\alpha$-amylase (B36), respectively.

Amino acid sequencing. An Applied Biosystems 470A sequencer was used for $\mathrm{NH}_{2}$-terminal amino acid sequence determination by automatic Edman degradation.

$D N A-D N A$ hybridization. This was done in the presence of $50 \%(\mathrm{v} / \mathrm{v})$ formamide at $38^{\circ} \mathrm{C}$ using as probe ${ }^{32} \mathrm{P}$-labelled pBR322 DNA from which the DraI-PvuII $1.4 \mathrm{~kb}$ fragment, containing the replication origin, had been removed.

\section{Results}

\section{Construction and analysis of plasmids pTUBE631 to pTUBE638 containing the amyE'-'pBR322'-'amyT fusion genes}

To insert segments of pBR322 DNA between the amy $E^{\prime}$ and 'amyT DNA region, pBR322 DNA was digested with HapII and HaeIII, and with HapII and Sau3AI. HindIII linker DNA was added to the resulting mixture, which, following $H$ indIII digestion, was inserted into the unique HindIII site of pTUBE627. The recombinant plasmids were introduced into $E$. coli $\mathrm{HB101}$, and DNA-DNA hybridization positive colonies were isolated. Eight representative transformants differing in 


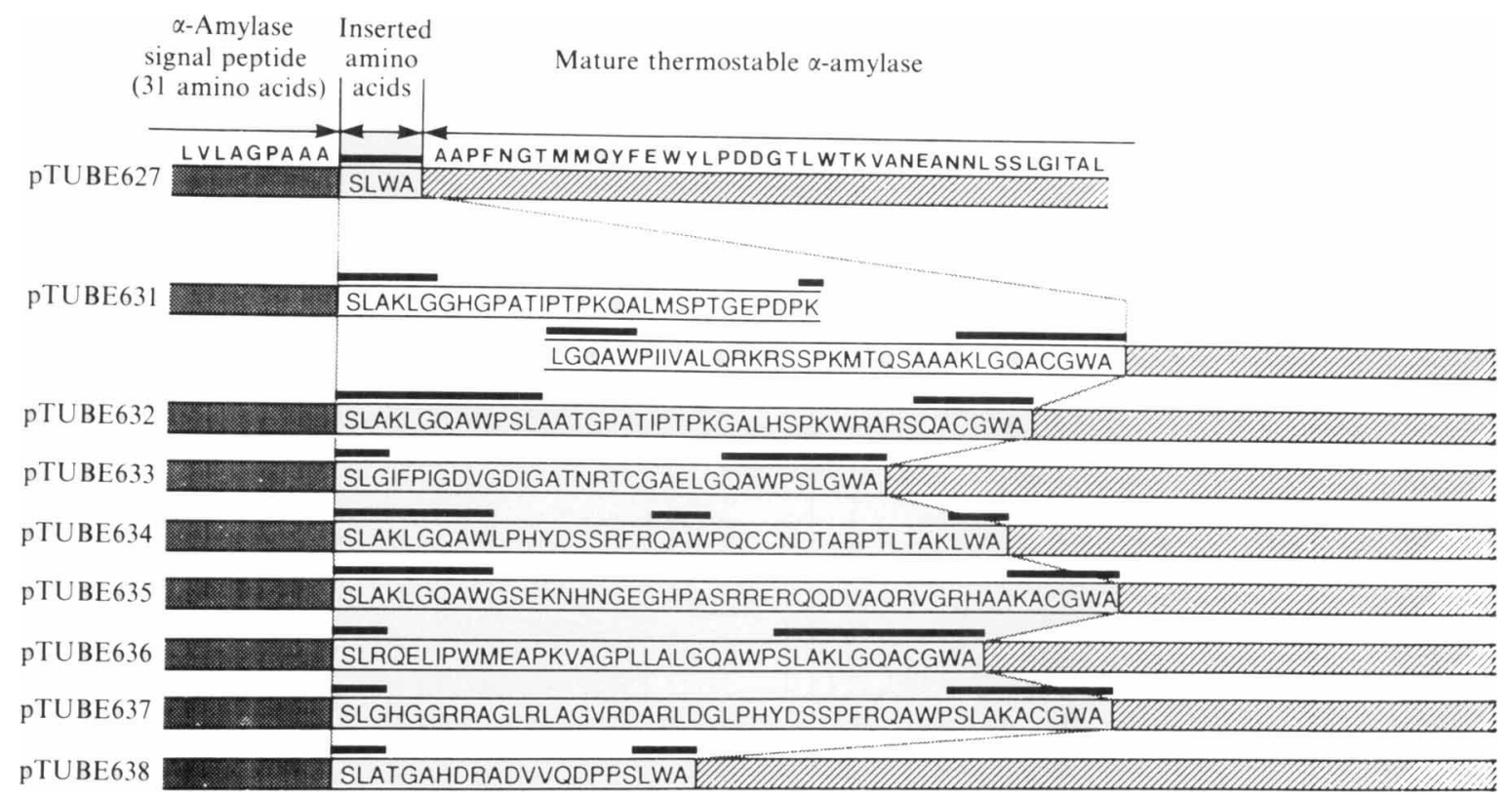

Fig. 1. Amino acid sequences of the inserted peptides, deduced from the DNA nucleotide sequences. The 31 amino acid sequence from the $\mathrm{NH}_{2}$-terminal $\mathrm{f}$-Met in the $B$. subtilis $\alpha$-amylase signal peptide. thermostable $\alpha$-amylase originating from $B$. stearothermophilus $\mathrm{A} 631$, in which the $\mathrm{NH}_{2}$-terminal amino acid (Ala) corresponds to position 36 from the $\mathrm{NH}_{2}$-terminal f-Met in the precursor protein from the amyT gene in pTUBE627 (Sohma et al., 1987). Thick lines indicate the amino acids encoded by the HindIII linker DNA.

the production of amylase were selected and their plasmids designated pTUBE631 to pTUBE638. The nucleotide sequences at and near the inserted fragments of pBR322 were determined and the amino acid sequences deduced (Fig. 1). Plasmids pTUBE631 and pTUBE634 contained two, different, fragments of pBR322 while all the others contained a single fragment. All of the small DNA fragments were derived from the ampicillin resistance or tetracycline resistance genes, except for the fragment in pTUBE638, in which a part of the $3^{\prime}$ flanking region of the tetracycline resistance gene was inserted. In all of these constructions, between 21 and 65 amino acid residues were added between the signal peptide and the mature enzyme.

\section{Effect of the inserted peptides on the production of} thermostable $\alpha$-amylases in $E$. coli and B. subtilis cells

The parental B. subtilis 207-25(pTUBE627) produced approximately $800 \mathrm{U}$ of extracellular thermostable $\alpha$-amylase $\mathrm{ml}^{-1}$ after $36 \mathrm{~h}$ of culture, and E. coli $\mathrm{HB} 101-$ (pTUBE627) produced $2000 \mathrm{U} \mathrm{ml}^{-1}$ of the periplasmic enzyme after $24 \mathrm{~h}$ of culture (Fig. $2 a, f$ ). As summarized in Fig. 2 and Table 1, in most cases the additional amino acid residues reduced the amount of enzyme produced. The degree of reduction varied with each peptide; $E$. coli HB101(pTUBE637), for example, produced only $1 \%$ of the amount of the enzyme produced by $E$. coli HB101(pTUBE627). In contrast, the quantity of the enzyme produced by $B$. subtilis $207-25$ (pTUBE638) was more than 1.7 times that produced by $B$. subtilis 207-25(pTUBE627), even though pTUBE638 had little or no enhancing activity in E. coli. The proportion of thermostable $\alpha$-amylases detected in the intracellular fractions of $B$. subtilis 207-25 carrying pTUBE635, pTUBE636 and pTUBE637, and E. coli HB101 carrying pTUBE636 and pTUBE637 appeared to be increased, presumably due to the decrease in the total amount of $\alpha$-amylases synthesized and unaltered levels of the activity retained in cells. Therefore, no increased accumulation of the extended enzymes was observed in the intracellular fractions of either $B$. subtilis or E. coli. These results indicate that the addition of specific amino acid sequences immediately after the signal peptide cleavage site may enhance the production of $\alpha$-amylase, although in most cases these sequences decreased the amount of enzyme secreted.

The specific activity of the thermostable $\alpha$-amylases (units per mg protein) in the periplasm of $E$. coli cells and in the culture supernatants of $B$. subtilis cells was similar to the activity of the parent when it was measured using a rabbit antiserum against thermostable $\alpha$-amylase produced by $B$. subtilis. Growth of the E. coli and B. subtilis transformants and copy number of the plasmids per cell were unaffected by the insertion mutations. There was 


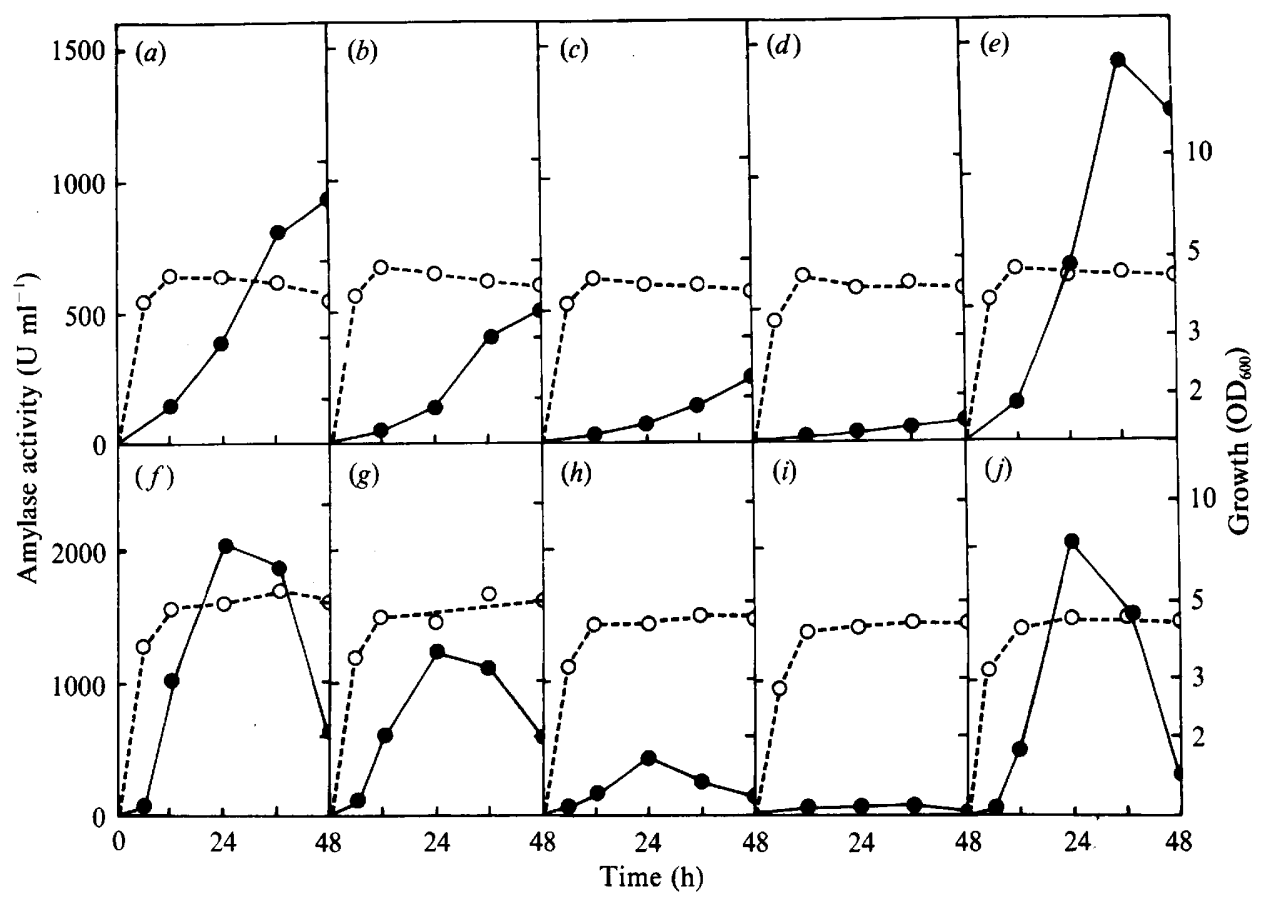

Fig. 2. Activity of thermostable $\alpha$-amylases in the extracellular fractions of $B$. subtilis 207-25 transformants carrying pTUBE627 (a), pTUBE631 (b), pTUBE633 (c), pTUBE637 $(d)$ and pTUBE638 $(e)$, and in the periplasm of the $E$. coli HB101 transformants carrying pTUBE627 $(f)$, pTUBE631 $(g)$, pTUBE633 $(h)$, pTUBE637 $(i)$ and pTUBE638 $(j)$. The cells were cultured in L-broth containing $10 \mu \mathrm{g}$ kanamycin $\mathrm{ml}^{-1}$ at $37^{\circ} \mathrm{C}$ and the cultures were fractionated. $-\bullet, \alpha$-Amylase activity; $0_{---} \bigcirc$, growth.

Table 1. Production and localization of thermostable $\alpha$-amylases from the mutated fusion genes in $E$. coli and $B$. subtilis transformants

\begin{tabular}{|c|c|c|c|c|c|c|c|c|c|c|}
\hline \multirow[b]{3}{*}{ Plasmid } & \multirow{3}{*}{$\begin{array}{l}\text { Length of } \\
\text { added } \\
\text { peptide }\end{array}$} & \multicolumn{5}{|c|}{ E. colit } & \multicolumn{4}{|c|}{ B. subtilis $\ddagger$} \\
\hline & & \multirow{2}{*}{$\begin{array}{c}\text { Total } \\
\text { activity } \\
\left(\mathrm{U} \mathrm{ml}^{-1}\right)\end{array}$} & \multicolumn{3}{|c|}{ Localization $(\%)$ in } & \multirow{2}{*}{$\begin{array}{c}\text { Ratio of } \\
\text { enzyme } \\
\text { production§ }\end{array}$} & \multirow{2}{*}{$\begin{array}{c}\text { Total } \\
\text { activity } \\
\left(\mathrm{U} \mathrm{ml}^{-1}\right)\end{array}$} & \multicolumn{2}{|c|}{ Localization $(\%)$ in } & \multirow{2}{*}{$\begin{array}{l}\text { Ratio of } \\
\text { enzyme } \\
\text { production§ }\end{array}$} \\
\hline & & & $\mathbf{E}$ & $\mathbf{P}$ & $\mathrm{C}$ & & & $\mathbf{E}$ & $\mathrm{C}$ & \\
\hline pTUBE627 & 4 & 2022 & 1 & 98 & 1 & 1.00 & 808 & 99 & 1 & 1.00 \\
\hline pTUBE631 & 65 & 1226 & 1 & 79 & 20 & 0.61 & 451 & 99 & 1 & 0.58 \\
\hline pTUBE632 & 42 & 335 & 4 & 75 & 21 & 0.17 & 178 & 99 & 1 & 0.22 \\
\hline pTUBE633 & 34 & 266 & 2 & 82 & 17 & 0.13 & 166 & 99 & 1 & 0.21 \\
\hline pTUBE634 & 40 & 208 & 11 & 67 & 22 & $0 \cdot 10$ & 104 & 93 & 7 & $0 \cdot 13$ \\
\hline pTUBE635 & 46 & 133 & 6 & 67 & 27 & 0.07 & 65 & 85 & 15 & 0.07 \\
\hline pTUBE636 & 39 & 94 & 1 & 22 & 75 & 0.05 & 48 & 80 & 20 & 0.06 \\
\hline pTUBE637 & 46 & 27 & 2 & 9 & 89 & 0.01 & 38 & 74 & 26 & 0.05 \\
\hline pTUBE638 & 21 & 2018 & 1 & 96 & 3 & 1.00 & 1443 & 99 & 1 & 1.79 \\
\hline
\end{tabular}

* Number of amino acid residues encoded in the inserted pBR322 DNA fragments and the HindIII linker DNA.

$\dagger$ The $E$. coli cells harbouring each of the plasmids were cultured in L-broth containing $10 \mu \mathrm{g}$ kanamycin ml $\mathrm{l}^{-1}$ at $37^{\circ} \mathrm{C}$ for $24 \mathrm{~h}$, and the cultures were fractionated into extracellular (E), periplasmic (P) and intracellular (C) fractions by the osmotic shock method of Chan et al. (1981).

$\ddagger$ Details as for $E$. coli, except that cultures were harvested after $36 \mathrm{~h}$ and fractionated into extracellular (E) and intracellular (C) fractions.

$\S$ Ratio of total amylase activity in $B$. subtilis or $E$. coli transformants to that of the respective parental strain.

no obvious direct relation between the lengths of the inserted peptides and enzyme production (Table 1). The smallest peptide, in pTUBE638, enhanced the extracellular production of the enzyme by $B$. subtilis. The effect of each inserted peptide on the production of the enzyme was similar in E. coli and B. subtilis cells, except for that encoded by pTUBE638.

\section{Processing of the $\mathrm{NH}_{2}$-terminally extended thermostable $\alpha$-amylases in $E$. coli and B. subtilis}

To analyse the processing system in $E$. coli and $B$. subtilis cells, the molecular masses of the exported thermostable $\alpha$-amylases were estimated by SDS-PAGE. After electrophoresis, the bands corresponding to the amylases were 

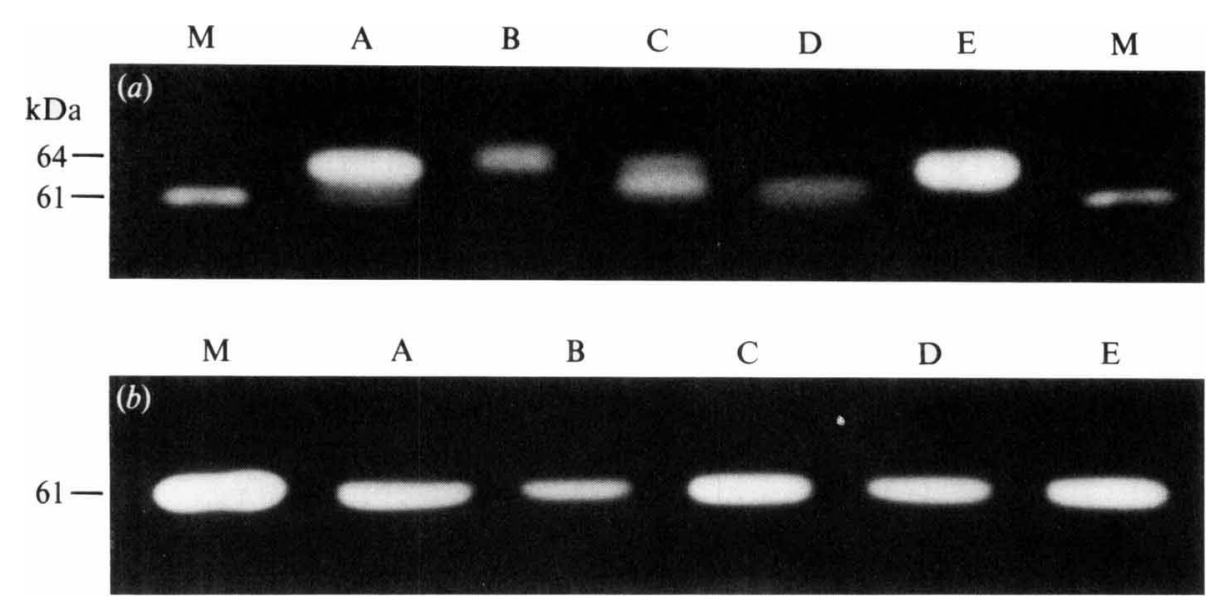

Fig. 3. (a) Different molecular masses of the periplasmic thermostable $\alpha$-amylases in $E$. coli HB101 containing pTUBE631 (A), pTUBE632 (B), pTUBE633 (C), pTUBE634 (D) or pTUBE638 (E). (b) Identical molecular masses of the extracellular thermostable $\alpha$-amylase from $B$. subtilis 207-25 containing pTUBE631 (A), pTUBE632 (B), pTUBE633 (C), pTUBE634 (D) or pTUBE638 (E). $\mathrm{M}$, extracellular mature thermostable $\alpha$-amylase obtained from the culture supernatant of the parental $B$. subtilis 207-25(pTUBE627). The $E$. coli and $B$. subtilis cells were cultured in L-broth containing $10 \mu \mathrm{g}$ kanamycin $\mathrm{ml}^{-1}$ for $36 \mathrm{~h}$ at $37^{\circ} \mathrm{C}$. The enzymes in the periplasmic fractions of $E$. coli cells and in the culture supernatant fractions from $B$. subtilis cells were analysed.
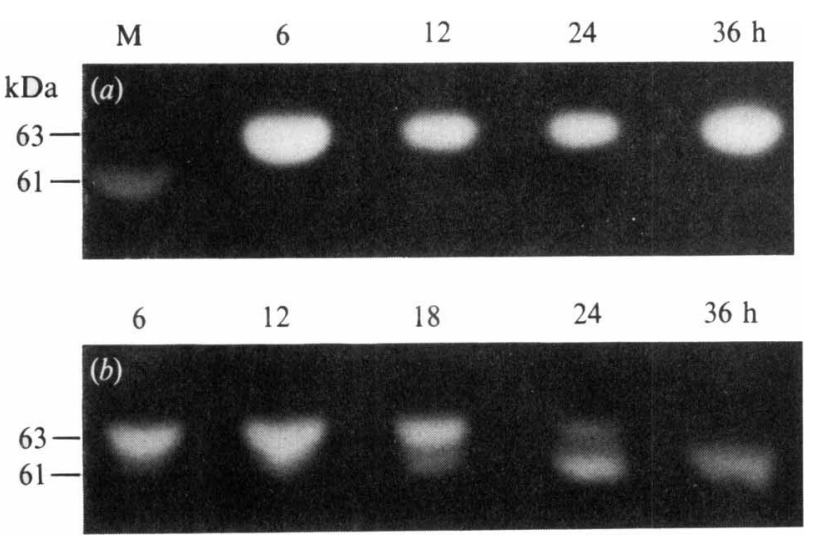

Fig. 4. (a) Identical molecular masses of the $\mathrm{NH}_{2}$-terminally extended thermostable $\alpha$-amylases in the periplasm of $E$. coli HB101(pTUBE638), and (b) variations in the molecular mass of the extended enzyme in the culture supernatant of $B$. subtilis 207-25(pTUBE638) during culture. The cultures were sampled at the time indicated, fractionated, and analysed. M, see Fig. 3.

visualized by their starch-hydrolysing activity (Fig. $3 a, b)$. The molecular masses of the $\mathrm{NH}_{2}$-terminally extended thermostable $\alpha$-amylases in the periplasmic fractions of $E$. coli HB101 carrying pTUBE631, pTUBE632, pTUBE633, pTUBE634 or pTUBE638 after $36 \mathrm{~h}$ of culture ranged from 61 to $64 \mathrm{kDa}$. In contrast, the molecular mass of each of the extracellular enzymes from $B$. subtilis $207-25$ carrying these plasmids after $36 \mathrm{~h}$ of culture was estimated to be $61 \mathrm{kDa}$, a value corresponding to that of the mature extracellular enzyme from B. subtilis 207-25(pTUBE627) and from B. stearo- thermophilus A631 (Sohma et al., 1987). The electrophoretic analysis of the $\alpha$-amylase preparations from the strains carrying pTUBE635, pTUBE636 and pTUBE637 was not possible due to their low activity.

The apparent molecular mass of the extended thermostable $\alpha$-amylase encoded by pTUBE638 in the periplasm of E. coli did not change throughout the 12 to $36 \mathrm{~h}$ period of culture. In contrast, the molecular mass of the extracellular enzyme from $B$. subtilis 207-25(pTUBE638) decreased from $63 \mathrm{kDa}$ in the early stage of culture $(6$ to $18 \mathrm{~h}$ ) to $61 \mathrm{kDa}$ in the later stages ( 24 to $36 \mathrm{~h}$ ) (Fig. $4 a, b$ ). The same result was observed by immunoblot analysis after the gel electrophoresis. These results suggest that the extended pTUBE638-encoded enzyme from the $B$. subtilis cells may have been processed to the mature form after it had been secreted into the culture medium, whereas the enzyme in the $E$. coli strain was translocated into the periplasm and remained there without removal of the inserted peptide.

In order to test this assumption, pTUBE638- $\alpha$-amylase (E24), pTUBE638- $\alpha$-amylase (B12) and pTUBE638$\alpha$-amylase (B36) were prepared and the amino acid sequences of their $\mathrm{NH}_{2}$-terminal regions were determined (Table 2). The sequence of pTUBE638- $\alpha$-amylase (E24) was found to be Ser-Leu-Ala-Thr-Gly-Ala-His, in which the $\mathrm{NH}_{2}$-terminal amino acid corresponds to position 32 from the $\mathrm{NH}_{2}$-terminal $\mathrm{f}$-Met. In contrast, the $\mathrm{NH}_{2}$-terminal amino acid sequence of pTUBE638$\alpha$-amylase (B12) was Thr-Gly-Ala-His-Asp-Arg-Ala, indicating that the sequence started from position 35 . Two $\mathrm{NH}_{2}$-terminal amino acid sequences (Ala-Ala-AlaPro-Phe-Asn-Gly and Ala-Ala-Pro-Phe-Asn-Gly-Thr) 


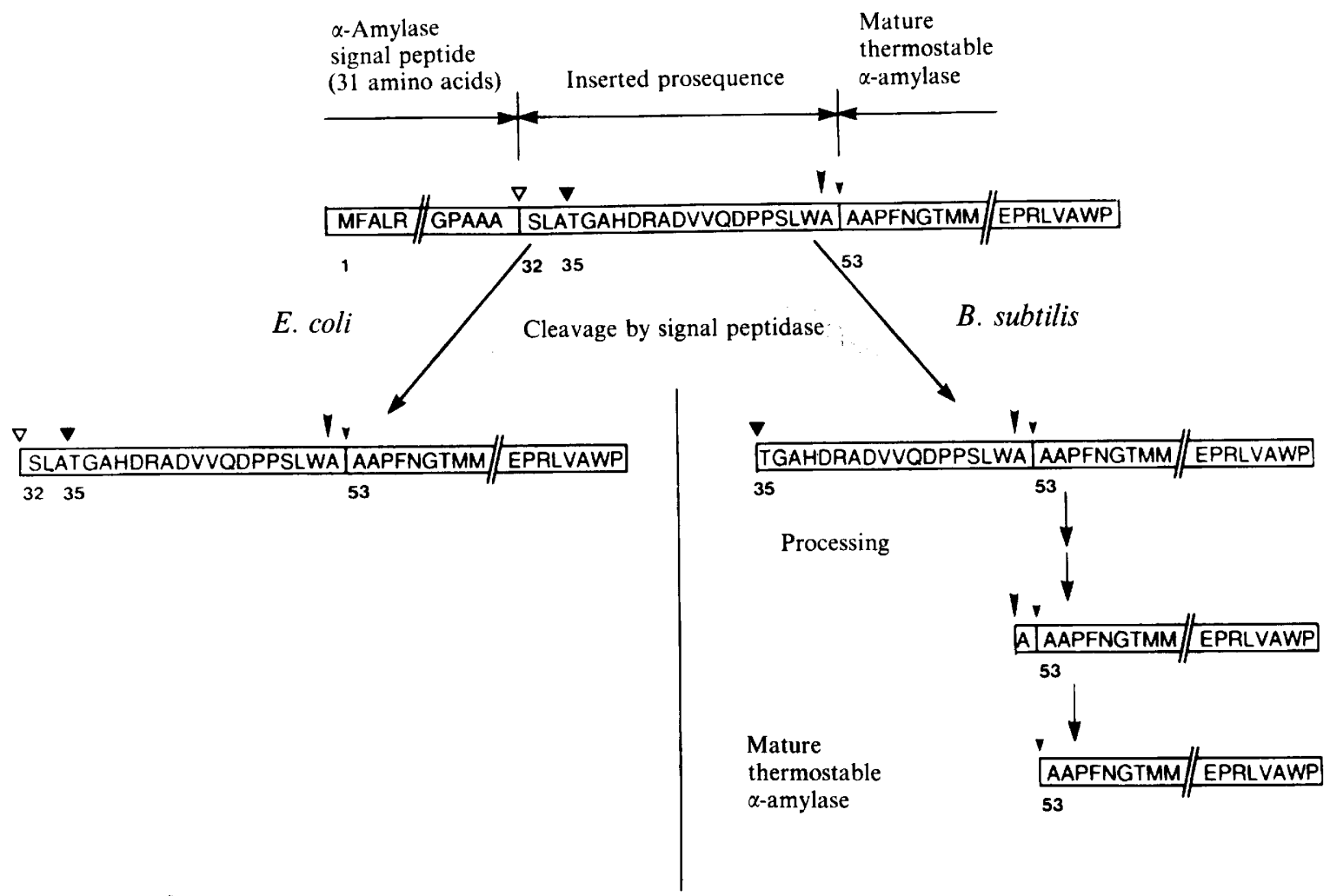

Fig. 5. Schematic representation of the cleavage of the signal peptide and processing of the precursor protein encoded by pTUBE638 in $E$. coli and B. subtilis. $\nabla$, Signal peptide cleavage site in $E$. coli; $\nabla$, signal peptide cleavage site in $B$. subtilis. $\mathbf{\nabla}$, $\nabla$, processing sites proposed based on the $\mathrm{NH}_{2}$-terminal amino acid sequences of the pTUBE638- $\alpha$-amylase (B36) preparation, which was purified from the culture supernatant of $B$. subtilis 207-25(pTUBE638) after $36 \mathrm{~h}$ of culture. Numbers under the amino acid residues indicate the positions from the $\mathrm{NH}_{2}$-terminal $\mathrm{f}$-Met.

Table 2. $\mathrm{NH}_{2}$-terminal amino acid sequences of the pTUBE638- $\alpha$-amylase (E24) preparation from $E$. coli, and the pTUBE638- $\alpha$-amylase $(B 12)$ and $(B 36)$ preparations from $B$. subtilis

Numbers in the parentheses indicate the amount (pmol) of amino acid residues recovered in each cycle.

\begin{tabular}{|c|c|c|c|c|}
\hline \multirow{3}{*}{$\frac{\text { Cycle }}{1}$} & \multirow{3}{*}{$\begin{array}{c}\frac{E . \text { coli }}{\text { pTUBE638- } \alpha \text {-amylase }}(\text { E24) } \\
\text { Ser }(11 \cdot 15)\end{array}$} & \multicolumn{3}{|c|}{ B. subtilis } \\
\hline & & $\begin{array}{l}\text { pTUBE638- } \alpha \text {-amylase } \\
\text { (B12) }\end{array}$ & \multicolumn{2}{|c|}{$\begin{array}{c}\text { pTUBE638- } \alpha \text {-amylase } \\
\text { (B36) }\end{array}$} \\
\hline & & Thr $(7 \cdot 14)$ & Ala $(120.74)$ & Ala (120.74) \\
\hline 2 & Leu $(41.75)$ & Gly $(29 \cdot 38)$ & Ala $(111.86)$ & Ala $(111.86)$ \\
\hline 3 & Ala $(51 \cdot 14)$ & Ala $(13.65)$ & Ala $(96.54)$ & Pro (24.53) \\
\hline 4 & Thr (12.61) & His $(1.79)$ & Pro $(79.25)$ & Phe $(20 \cdot 60)$ \\
\hline 5 & Gly (48.59) & Asp $(9.09)$ & Phe $(64 \cdot 64)$ & Asn $(14.81)$ \\
\hline 6 & Ala $(45.35)$ & Arg (3.85) & Asn (41.98) & Gly $(32.67)$ \\
\hline 7 & His $(1.50)$ & Ala $(9.54)$ & Gly $(61 \cdot 78)$ & Thr $\quad(3.84)$ \\
\hline 8 & Asp (16.84) & Pro $(11.02)$ & Thr $\quad(7.41)$ & $(8 \cdot 37)$ \\
\hline 9 & Arg $(4 \cdot 15)$ & Val $(5 \cdot 10)$ & Met $(29.30)$ & Met $(29 \cdot 30)$ \\
\hline 10 & Ala $(32 \cdot 23)$ & Val (6.64) & Met $(31 \cdot 62)$ & Gln $(33.60)$ \\
\hline
\end{tabular}


were found in the pTUBE638- $\alpha$-amylase (B36), in which the amino acid sequences started at positions 52 and 53 , respectively. Since the molar ratios of the recovered Pro, Phe, and Asn residues in the former and the latter cycles of the amino acid sequence analysis of pTUBE638$\alpha$-amylase (B36) were approximately $1: 3$ (Table 2 ), we considered that the pTUBE638- $\alpha$-amylase (B36) preparation consists of the two thermostable $\alpha$-amylases starting at positions 52 and 53 in the ratio of $3: 1$. The sequence Ala-Ala-Pro-Phe-Asn, starting at position 53, was found at the $\mathrm{NH}_{2}$-terminus of the extracellular mature thermostable $\alpha$-amylase from $B$. stearothermophilus A631 (Sohma et al., 1987). These results indicate that the precursor expressed from pTUBE638 in the $E$. coli cells was cleaved between Ala-31 and Ser-32 by a signal peptidase, and that the resulting extended thermostable $\alpha$-amylase was translocated into the periplasm, where it remained without removal of the inserted peptide. In contrast, the precursor synthesized in $B$. subtiiis was first cleaved between Ala-34 and Thr-35, the extended thermostable $\alpha$-amylase was secreted into the culture medium and then the additional amino acid residues from positions 35 ( $\mathrm{Thr}$ ) to 52 (Ala) were processed as illustrated in Fig. 5. The pTUBE638$\alpha$-amylase (B36) starting from position 52 (Ala) may be considered as an intermediate. Based on the analyses of the molecular masses and $\mathrm{NH}_{2}$-terminal amino acid sequences of the extended and the mature thermostable $\alpha$-amylases from pTUBE638, it can be assumed that the conversion from the $\mathrm{NH}_{2}$-terminally extended form of the enzyme to the mature one proceeds in a stepwise manner. However, the number of steps involved in the processing of the enzymes remained to be determined.

\section{Discussion}

The deduced amino acid sequence around the signal peptide cleavage site of the precursor encoded by pTUBE638 is shown in Figs 1 and 5. On the basis of the analysis of the $\mathrm{NH}_{2}$-terminal amino acid sequences in the pTUBE638- $\alpha$-amylases (E24) and (B12), the signal peptide cleavage site of the precursor in $E$. coli was found to be located between Ala-31 and Ser-32, and in $B$. subtilis between Ala-34 and Thr-35. The amino acids at positions 33 and 34 in this precursor were Leu and Ala, and the peptide bond between them was not cleaved in $B$. subtilis cells, although the signal peptide cleavage site of the $B$. subtilis $\alpha$-amylase precursor was found to be located between Ala-33 and Glu-34 by Takase et al. (1988) and Sasamoto et al. (1989). This result indicates that the signal peptide cleavage site is alterable in $B$. subtilis cells. In these cells, the precursor of
pTUBE638 could have been first cleaved between Ala-31 and Ser-32 as in the case of $E$. coli and in a previous paper (Sohma et al., 1987), and then immediately three amino acids at positions 32 (Ser), 33 (Leu) and 34 (Ala) could have been removed by some protease(s) or peptidase(s). However, none of the amino acids involved were present in detectable amounts, suggesting that the formation of a cleavage product with a $\mathbf{N H}_{2}$-terminal amino acid corresponding to Ser-32 is unlikely. This implies a difference in the cleavage site of the precursor protein encoded by pTUBE638 in $B$. subtilis and $E$. coli. The difference may be related to the finding that the signal peptides of $B$. subtilis extracellular enzymes were 8 to 10 amino acid residues longer than those of periplasmic and outer-membrane proteins in E. coli (Watson, 1984; Von Heijne \& Abrahmsen, 1989). A different processing site for $B$. stearothermophilus $\alpha$-amylase in $E$. coli was also reported by Suominen et al. (1987).

After the removal of the signal peptides, the resulting $\mathrm{NH}_{2}$-terminally extended thermostable $\alpha$-amylases were located in the $E$. coli periplasm and were secreted into the culture medium by $B$. subtilis. Based on the molecular masses of the extended $\alpha$-amylases and the $\mathrm{NH}_{2}$-terminal amino acid sequences of pTUBE638-encoded amylases from $E$. coli and B. subtilis, it appears that in $E$. coli each of the inserted peptides was processed differently, while in $B$. subtilis all the extended enzymes were processed to the mature form. The results suggest that in $B$. subtilis the processing of the extended enzymes into the mature form is done by extracellular protease(s) or peptidase(s) which have a wide substrate specificity like subtilisin.

In summary, artificially inserted peptides between the signal peptide and mature thermostable $\alpha$-amylase were able to modulate the production of thermostable $\alpha$-amylases in $E$. coli and $B$. subtilis. The $\mathrm{NH}_{2}$-terminally extended enzymes were translocated into the periplasm of $E$. coli and were secreted into the culture medium by B. subtilis after the signal peptide was removed. The extended propeptides were rapidly processed in $B$. subtilis. The signal peptide cleavage site of a precursor protein was different in $E$. coli and $B$. subtilis.

This work was supported in part by a Grant-in-Aid from the Ministry of Education, Sciences and Culture of Japan.

\section{References}

BiRnBoim, H. C. \& Doly, J. (1979). A rapid alkaline extraction procedure for screening recombinant plasmid DNA. Nucleic Acids Research 7, 1513-1523

Blobel, G. \& DobBerstein, B. (1975). Transfer of proteins across membranes. Journal of Cell Biology 67, 835-851.

Chan, S. J., Weiss, J., KonRad, M., White, T., Bahl, C., Yu, S.-D., MARKS, D. \& STEINER, D. F. (1981). Biosynthesis and periplasmic segregation of human proinsulin in Escherichia coli. Proceedings of the National Academy of Sciences of the United States of America 78, 5401-5405. 
Chang, S. \& CoHEN, S. N. (1979). High frequency transformation of Bacillus subtilis protoplasts by plasmid DNA. Molecular and General Genetics 168, 111-115.

DAvIS, B. D. \& TAI, P.-C. (1980). The mechanism of protein secretion across membranes. Nature, London 283, 433-438.

Dretzen, G., Bellard, M., Sassone-Corsi, P. \& Chambon, P. (1981). A reliable method for the recovery of DNA fragments from agarose and acrylamide gels. Analytical Biochemistry 112, 295-298.

FULLER, R. S., STERNE, R. E. \& THORNER, J. (1988). Enzymes required for yeast prohormone processing. Annual Review of Physiology 50, 345-362.

FUWA, H. (1954). A new method for microdetermination of amylase activity by the use of amylose as the substrate. Journal of Biochemistry 41, 583-603.

IKEMURA, H. \& INOUYE, M. (1988). In vitro processing of prosubtilisin produced in Escherichia coli. Journal of Biological Chemistry 263, 12959-12963.

IKemura, H., TAKaGI, H. \& INOUYe, M. (1987). Requirement of prosequence for the production of active subtilisin $\mathrm{E}$ in Escherichia coli. Journal of Biological Chemistry 262, 7859-7864.

LACKS, S. A. \& Springhorn, S. S. (1980). Renaturation of enzymes after polyacrylamide gel electrophoresis in the presence of sodium dodecyl sulfate. Journal of Biological Chemistry 255, 7467-7473.

LAEMMLI, U. K. (1970). Cleavage of structural proteins during the assembly of the head of bacteriophage T4. Nature, London 227, 680-685.

LEDERBERG, E. M. \& Cohen, S. N. (1974). Transformation of Salmonella typhimurium by plasmid deoxyribonucleic acid. Journal of Bacteriology 119, 1072-1074.

MÄNTSÄLÄ, P. \& ZALKIN, H. (1979). Membrane-bound and soluble extracellular $\alpha$-amylase from Bacillus subtilis. Journal of Biological Chemistry 254, 8540-8547.

NeURath, H. \& Walsh, K. A. (1976). Role of proteolytic enzymes in biological regulation. Proceedings of the National Academy of Sciences of the United States of America 73, 3825-3832.

Nielsen, J. B. K. \& LAMPEN, J. O. (1982). Membrane-bound penicillinase in gram-positive bacteria. Journal of Biological Chemistry 257, 4490-4495.

SANGer, F., Nicklen, S. \& Coulson, A. R. (1977). DNA sequencing with chain-terminating inhibitors. Proceedings of the National Academy of Sciences of the United States of America 74, 5463-5467.

Sasamoto, H., Nakazawa, K., Tsutsumi, K., Takase, K. \& Yamane, K. (1989). Signal peptide of Bacillus subtilis $\alpha$-amylase. Journal of Biochemistry 106, 376-382.

SHORTLE, D. (1983). A genetic system for analysis of staphylococcal nuclease. Gene 22, 181-189.
Sohma, A., Fujita, T. \& Yamane, K. (1987). Protein processing to form extracellular thermostable $\alpha$-amylases from a gene fused in a Bacillus subtilis secretion vector. Journal of General Microbiology 133, 3271-3277.

Steiner, D. F., QuinN, P. S., Chan, S. J., Marsh, J. \& Tager, H. S. (1980). Processing mechanisms in the biosynthesis of proteins. Annals of the New York Academy of Sciences 343, 1-16.

SuOMinen, I., KarP, M., Lautamo, J., KNowles, J. \& Mäntsälä, P (1987). Thermostable $\alpha$-amylase of Bacillus stearothermophilus: cloning, expression, and secretion by Escherichia coli. In Extracellular Enzymes of Microorganisms, pp. 129-137. Edited by J. Chaloupka \& V. Krumphanzl. New York: Plenum Press.

TabaK, H. F. \& Flavell, R. A. (1978). A method for the recovery of DNA from agarose gels. Nucleic Acids Research 5, 2321-2332.

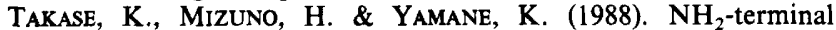
processing of Bacillus subtilis $\alpha$-amylase. Journal of Biological Chemistry 263, 11548-11553.

Vandekerckhove, J., Bauw, G., Puype, M., Van Dame, J. \& Van MonTAGU, M. (1985). Protein-blotting on polybrene-coated glassfiber sheets. European Journal of Biochemistry 152, 9-19.

Von HeIJNE, G. \& ABRaHmSEN, L. (1989). Species-specific variation in signal peptide design: implications for protein secretion in foreign hosts. FEBS Letters 244, 439-446.

Watson, M. E. E. (1984). Compilation of published signal sequences. Nucleic Acids Research 12, 5145-5164.

WoNG, S.-L. \& DoI, R. H. (1986). Determination of the signal peptidase cleavage site in the preprosubtilisin of Bacillus subtilis. Journal of Biological Chemistry 261, 10176-10181.

Yamane, K., Takeichi, Y., Masuda, T., Kawamura, F. \& Saito, H. (1982). Construction and physical map of a Bacillus subtilis specialized transducing phage $\rho 11$ containing Bacillus subtilis $l^{+} \mathrm{s}^{+}$ gene. Journal of General and Applied Microbiology 28, 417-428.

Yamazaki, H., Ohmura, K., Nakayama, A., Takeichi, Y., OtozaI, K., Yamasaki, M., TAMURa, G. \& Yamane, K. (1983). $\alpha$-Amylase genes (amyR2 and $a m y E$ ) from an $\alpha$-amylase-hyperproducing Bacillus subtilis strain: molecular cloning and nucleotide sequences. Journal of Bacteriology 156, 327-337.

Yang, M. Y., Ferrari, E. \& Henner, D. J. (1984). Cloning of the neutral protease gene of Bacillus subtilis and the use of the cloned gene to create an in vitro-derived deletion mutation. Journal of Bacteriology 160, 15-21.

Yanisch-Perron, C., Vieira, J. \& Messing, J. (1985). Improved M13 phage cloning vectors and host strains: nucleotide sequences of M13 mp18 and pUC19 vectors. Gene 33, 103-119. 